\title{
Immunological Properties of the Cell Envelope Components of Vibrio cholerae
}

\author{
By S. KABIR ${ }^{1 * \dagger}$ AND P. MANN ${ }^{2}$ \\ 1 School of Medicine, Johns Hopkins University, Baltimore, Maryland 21224, U.S.A. \\ ${ }^{2}$ Laboratory of Cellular and Comparative Physiology, Gerontology Research Center, \\ National Institute of Aging, National Institutes of Health, \\ Baltimore, Maryland 21224, U.S.A.
}

(Received 29 October 1979; revised 22 January 1980)

\begin{abstract}
Several immunobiological properties of cell envelope components of Vibrio cholerae such as mitogenicity, antigenicity, adjuvanticity and toxicity were tested in mice. Killed whole bacteria, spheroplasts, lipopolysaccharide and outer membrane proteins possessed mitogenic activity as determined by $\left[{ }^{3} \mathrm{H}\right]$ thymidine uptake in spleen cell cultures. All these components predominantly stimulated murine bone-marrow derived (B) lymphocytes. The mitogenicity induced by $V$. cholerae lipopolysaccharide was similar in magnitude to that observed with Salmonella typhimurium lipopolysaccharide. Vibrio cholerae lipopolysaccharide was mitogenic for gut-associated lymphocytes such as those obtained from Peyer's patches and small intestine. Antibody formation at the cellular level was detected by the haemolytic plaque assay. Plaque-forming cells to $V$. cholerae lipopolysaccharide were only detected when mice were immunized intraperitoneally with intact cells or with spheroplasts. Among the various cell envelope components, lipopolysaccharide alone possessed adjuvant properties as it increased the number of plaque-forming cells to sheep erythrocytes fourfold in mouse spleens. Also, lipopolysaccharide was the only component found to be toxic for the mouse $\left(L_{50} 0.5 \mathrm{mg}\right)$. Neither spheroplasts nor outer membrane of $V$. cholerae showed adjuvanticity or toxicity in mice.
\end{abstract}

\section{INTRODUCTION}

The cell envelope of Vibrio cholerae is morphologically similar to that of another Gram-negative bacterium, Escherichia coli (Kennedy \& Richardson, 1969). It consists of three distinct layers: the outer membrane, the peptidoglycan and the inner or the cytoplasmic membrane. The outer membrane contains lipopolysaccharide (LPS), protein and lipid, while the inner or cytoplasmic membrane consists of protein and lipid. In Gram-negative bacteria, both LPS and protein moieties remain exposed on the cell surface (Shands, 1966; Kabir, 1975; Rittenhouse et al., 1973) and it is most likely that these components play a role in the interaction of the bacterium and the host during infection. Among the various cell envelope components of Gram-negative bacteria, LPS has received most attention and has been found to have a variety of immunological effects in the susceptible host (Kass \& Wolff, 1973). It is uncertain whether other components of the cell surface such as membrane proteins are also endowed with endotoxin-like properties.

There is evidence based on well-controlled field trials that killed whole cell vaccine, administered parenterally, is protective against cholera for limited periods of time and the immunity induced is antibacterial in nature (Mosley et al., 1969). However, little is

$\dagger$ Present address: International Centre for Diarrhoeal Disease Research, Bangladesh, G.P.O. Box 128, Dacca-2, Bangladesh. 
known about the immunological properties of the cell surface components of $V$. cholerae. Therefore, the present investigation was initiated to study in detail, in the mouse, immunobiological properties such as mitogenicity, antigenicity, adjuvanticity and toxicity induced by various cell envelope components of $V$. cholerae (intact cells, spheroplasts containing both inner and outer membranes, LPS and outer membrane).

\section{METHODS}

Animals. Female C57BL/6 mice, 6 to 8 weeks old, were used.

Bacterial strain and growth conditions. Vibrio cholerae strain 395 (Ogawa) was grown in Syncase medium (Finkelstein et al., 1966) at $37^{\circ} \mathrm{C}$ by shaking in a water bath. Cultures were harvested during the stationary phase. Bacteria were mixed with $1 \%$ formalin for $1 \mathrm{~h}$ and dried by subsequent treatment with acetone. This procedure was followed to prepare killed organisms.

Media and reagents. All tissue cultures were grown in RPMI-1640 (Grand Island Biological Co., Grand Island, New York, U.S.A.) supplemented with L-glutamine $(2 \mathrm{~mm})$, penicillin $\mathrm{G}\left(100\right.$ units $\left.\mathrm{ml}^{-1}\right)$ and streptomycin $\left(100 \mu \mathrm{g} \mathrm{ml}^{-1}\right)$.

Isolation of LPS. LPS was extracted from bacteria by the phenol/water procedure of Westphal et al. (1952). The crude product was further purified to remove proteins and nucleic acids by procedures involving repeated ultracentrifugation at $105000 \mathrm{~g}$ (Westphal \& Jann, 1965). Protein content was estimated by the Lowry method, using bovine serum albumin as a standard. Carbohydrate was determined by the phenol/sulphuric acid method (Dubois et al., 1956) using glucose as a standard.

Isolation of spheroplasts and outer membrane. Flagella were removed by shearing the bacteria at $4{ }^{\circ} \mathrm{C}$ in a Waring blender at high speed for $45 \mathrm{~s}$. The suspension was diluted sixfold in $0 \cdot 1 \mathrm{M}-\mathrm{Tris} / \mathrm{HCl}(\mathrm{pH} 7.8)$ and centrifuged at $1600 \mathrm{~g}$ for $15 \mathrm{~min}$. The spheroplasts were prepared from the non-flagellated bacteria according to the procedure of Osborn \& Munson (1975). Ten ml 0.01 M-Tris/HCl (pH 7.8) containing 0.75 $\mathrm{M}$-sucrose and $0.5 \mathrm{ml}$ lysozyme $\left(2 \mathrm{mg} \mathrm{ml}^{-1}\right.$ in water) were added to $1 \mathrm{~g}$ of the non-flagellated bacteria and the mixture was incubated at $4{ }^{\circ} \mathrm{C}$ for $2 \mathrm{~min}$ in an ice bath. Then $20 \mathrm{ml}$ cold EDTA $(1.5 \mathrm{~mm})$ was added slowly to the cell suspension. After $3 \mathrm{~h}$ incubation at $4^{\circ} \mathrm{C}, 0.4 \mathrm{ml} 1 \mathrm{M}-\mathrm{MgCl}_{2}, 0.3 \mathrm{mg}$ DNAase and $0.3 \mathrm{mg}$ RNAase were added to the mixture and allowed to stand for $10 \mathrm{~min}$. The suspension was centrifuged at $20000 \mathrm{~g}$. The formation of spheroplasts was monitored by phase contrast microscopy. Spheroplasts were washed once with $10 \mathrm{ml} 0.01 \mathrm{M}-\mathrm{Tris} / \mathrm{HCl}\left(\mathrm{pH} \mathrm{7.8)}\right.$ containing $0.01 \mathrm{M}-\mathrm{MgCl}_{2}$. The outer membrane was isolated according to the procedure of Schnaitman (1971). Spheroplasts prepared from $1 \mathrm{~g}$ bacteria were extracted with $10 \mathrm{ml}$ $2 \%(\mathrm{w} / \mathrm{v})$ Triton X-100 in $0.1 \mathrm{M}$-Tris/HCl containing $5 \mathrm{mM}$-EDTA and the supernatant was discarded.

Enzyme assay. The NADH oxidase activity in the outer membrane was assayed as described by Osborn et al. (1972). The incubation mixture for the measurement of NADH oxidase specific activity contained $50 \mathrm{~mm}-\mathrm{Tris} / \mathrm{HCl}(\mathrm{pH} 7.5), 0.12 \mathrm{~mm}-\mathrm{NADH}, 0.2 \mathrm{~mm}$-dithiothreitol and the membrane preparation $(0.1$ to $0.2 \mathrm{mg}$ protein) in a total volume of $1.0 \mathrm{ml}$. The rate of decrease in absorbance at $340 \mathrm{~nm}$ at $25^{\circ} \mathrm{C}$ was measured.

Preparation of outer membrane proteins. Lyophilized outer membrane $(10 \mathrm{mg})$ was extracted with $1 \mathrm{ml}$ of a buffer containing $0.05 \mathrm{M}$-glycine, $0.001 \mathrm{M}$-EDTA and $0.5 \%(\mathrm{w} / \mathrm{v})$ sodium deoxycholate, adjusted to $\mathrm{pH} 9$ with $\mathrm{NaOH}$, for $1 \mathrm{~h}$ at room temperature. The suspension was centrifuged at $10000 \mathrm{~g}$ for $15 \mathrm{~min}$. The residue contained the outer membrane proteins.

Both the outer membrane and the outer membrane proteins were subjected to immunoelectrophoresis after solubilization in the non-ionic detergent Tween 20 (Quality SD, Atlas Chemie, Essen, Germany). Briefly, 1 vol. $0.01 \mathrm{M}$-Tris $/ \mathrm{HCl}$ buffer (pH 8.0) containing $5 \%$ (w/v) Tween 20 was added to 1 vol. membrane suspension. After $2 \mathrm{~h}$ at room temperature, the mixture was centrifuged at $50000 \mathrm{~g}$. The supernatant was subjected to immunoelectrophoresis in a barbital buffer $(\mathrm{pH} 8.2)$ in $2 \%(\mathrm{w} / \mathrm{v})$ agarose for $1 \mathrm{~h}$. The pattern of immunoprecipitation was allowed to develop against antiserum to $V$. cholerae spheroplasts. This antiserum was raised in New Zealand white rabbits by injecting each rabbit with $1 \mathrm{mg} V$. cholerae spheroplasts, suspended in an emulsion of $0.5 \mathrm{ml}$ phosphate-buffered saline (PBS, pH 7.4) and $0.5 \mathrm{ml}$ Freund's incomplete adjuvant (Behringwerke, Marburg/Lahn, Germany). The spheroplasts were administered on days $0,14,28$ and 42 . One week after the last injection blood was collected. The resulting antiserum was stored at $-70^{\circ} \mathrm{C}$ until used.

Spleen cell cultures. Mice were killed by cervical dislocation and their spleens were removed aseptically. Single cell suspensions from individual spleens were prepared by passing the tissue through an 80 mesh stainless steel screen into RPMI-1640 medium supplemented with $10 \%$ (v/v) heat-inactivated foetal calf serum. Cells were washed thrice in the medium and separated by centrifugation at $200 \mathrm{~g}$. Cell viability was determined by Trypan Blue exclusion. Unless otherwise stated, spleen cells $\left(5 \times 10^{5}\right)$ were cultured in a humidified atmosphere containing $5 \% \mathrm{CO}_{2}$ at $37^{\circ} \mathrm{C}$ in Micro Test II plates (Falcon Products, Oxnard, 
Calif., U.S.A.) with different doses of $V$. cholerae fractions. For the last $16 \mathrm{~h}$ of the culture, cells were pulsed with $\left[{ }^{3} \mathrm{H}\right]$ thymidine $(1 \mu \mathrm{Ci}, 37 \mathrm{kBq})$. The cultures were harvested with an automatic harvester on to glass fibre strips, washed with at least $20 \mathrm{vol}$. saline solution and air-dried. After drying, the filter discs were placed in $3 \mathrm{ml}$ of a xylene-based scintillation fluid and stored for $24 \mathrm{~h}$ in the dark at $4{ }^{\circ} \mathrm{C}$ before counting in a scintillation counter (Mann, 1978).

Separation of $T$ and $B$ lymphocytes using a nylon wool column. The procedure of Handwerger \& Schwartz (1974) was used to separate murine spleen lymphocytes into T and B populations. The purity of the nylon adherent (B) and nylon non-adherent $(T)$ populations was checked by immunofluorescent techniques with fluorescein-conjugated, rabbit antimouse Ig as previously described (Greaves, 1970). The nylon adherent cell populations (B) were found to be $85 \%$ Ig-positive, while the non-adherent populations ( $T$ ) contained very few Ig-positive cells $(<3 \%)$.

Isolation of Peyer's patch and intestinal mucosal lymphoid cells. Peyer's patches were carefully excised from the small intestine and teased to obtain single cell suspensions. Approximately $5 \times 10^{6}$ lymphocytes were obtained from seven or eight Peyer's patches. Murine intestinal lymphocytes were isolated according to the procedure described by Cebra et al. (1977). The small intestine, devoid of Peyer's patches, was cut into pieces $3 \mathrm{~cm}$ long. The segments were everted on a Pasteur pipette and washed briefly in $\mathrm{Ca}^{2+} / \mathrm{Mg}^{2+}-$ free balanced salt solution (CMF-HBSS), prepared as described by Hudson \& Hay (1976). They were then incubated with stirring for $15 \mathrm{~min}$ at room temperature in CMF-HBSS and placed in CMF-HBSS containing 0.75 mm-EDTA. The $\mathrm{pH}$ was kept constant between 7.2 and 7.4 by the addition of $7.5 \%(\mathrm{w} / \mathrm{v}) \mathrm{NaHCO}_{3}$. Gut pieces were then treated for $1 \mathrm{~h}$ with collagenase (10 units $\mathrm{ml}^{-1}, 20 \mathrm{ml}$ per gut; Sigma) in RPMI-1640 at room temperature. The cell suspension was filtered through a gauze to remove debris, placed over a layer of Ficoll-Hypaque (Pharmacia) and centrifuged at $400 \mathrm{~g}$ for $40 \mathrm{~min}$ at $20^{\circ} \mathrm{C}$. About $5 \times 10^{6}$ lymphocytes were isolated per mouse gut.

Immunizing cgents. Mice were immunized intraperitoneally with $0.5 \mathrm{ml}$ of a washed sheep red blood cell (SRBC) suspension $(10 \%, \mathrm{v} / \mathrm{v})$. Immunization with $0.5 \mathrm{ml}$ of $10 \%(\mathrm{v} / \mathrm{v})$ SRBC suspension with different doses of the cell envelope components was used to assess their adjuvant properties. Direct splenic antibody plaque-forming cells (PFC) were counted $5 \mathrm{~d}$ after primary immunization.

Plaque assay. The number of PFC was estimated to two antigens, SRBC and $V$. cholerae LPS, in murine spleens. PFC to SRBC were detected by an agar plaque method similar to that developed by Jerne \& Nordin (1963). In this, $10^{6}$ nucleated spleen cells $(50 \mu \mathrm{l})$, a suspension of SRBC $(30 \%, \mathrm{v} / \mathrm{v} ; 50 \mu \mathrm{l})$ and $1 \%(\mathrm{w} / \mathrm{v}) \mathrm{agar}$ in minimum essential medium (MEM, Grand Island Biological Co.; $400 \mu \mathrm{l}$ ) were mixed, plated on a slide and incubated at $37^{\circ} \mathrm{C}$ for $1 \mathrm{~h}$. The slide was then washed and incubated with a $1: 10$ dilution of guinea pig complement. After further incubation for $1 \mathrm{~h}$, the number of direct PFC was determined.

The technique employed to count PFC to $V$. cholerae LPS was similar to that described by Jerne \& Nordin (1963) with some modifications. The LPS-coated SRBC were used as indicator cells. The coating method described here was not significantly different from that described by Möller (1965). Routinely, 5 mg LPS was dissolved in $5 \mathrm{ml}$ PBS (pH 7.4) and the solution was heated at $100^{\circ} \mathrm{C}$ in a water bath for $2 \mathrm{~h}$. One $\mathrm{ml}$ of packed SRBC was added to $5 \mathrm{ml}$ of the heated LPS solution and the mixture was shaken at $37^{\circ} \mathrm{C}$ for $1 \mathrm{~h}$. The suspension was centrifuged at $200 \mathrm{~g}$, washed thrice with PBS and adjusted to $30 \%$ (v/v) with PBS.

To confirm that anti-LPS immunoglobulins would be detected in a test involving lysis of LPS-coated erythrocytes, haemolytic tests were performed. Antiserum to $V$. cholerae LPS was raised in young New Zealand white rabbits (about $3 \mathrm{~kg}$ ) by repeated intravenous immunization with $V$. cholerae LPS $(0 \cdot 1 \mathrm{mg}$ $\mathrm{ml}^{-1}$ in PBS) according to the following schedule: day $10.5 \mathrm{ml}$, day $41.0 \mathrm{ml}$, day $81.5 \mathrm{ml}$, day $122.0 \mathrm{ml}$, day $192.5 \mathrm{ml}$, day $263.0 \mathrm{ml}$. Boosters of $3.0 \mathrm{ml}$ were given fortnightly for the next 8 weeks. Rabbits were bled 1 week after the last injection. The immunoglobulins to LPS were purified by affinity chromatography using insoluble matrices of $V$. cholerae LPS covalently coupled to AH-Sepharose 4B (Pharmacia) according to the procedure of Axén et al. (1967). The immunoglobulins to LPS were dissociated from the column by applying $0 \cdot 1 \mathrm{M}$-glycine/ $\mathrm{HCl}$, pH $2 \cdot 3$. For haemolysis, $0 \cdot 1 \mathrm{ml}$ anti-LPS immunoglobulins was serially diluted in PBS (pH 7.4) in microtitre plates and $0 \cdot 1 \mathrm{ml}$ of $2 \%(\mathrm{v} / \mathrm{v}) V$. cholerae LPS-coated SRBC was added to each well, followed by $0 \cdot 1 \mathrm{ml}$ of guinea pig complement diluted $1: 10$. The plates were incubated for $1 \mathrm{~h}$ at $37^{\circ} \mathrm{C}$ and the last well showing $100 \%$ lysis was taken as the end-point. Control experiments with uncoated erythrocytes were performed in parallel.

Toxicity test. The test substance was injected intraperitoneally in $0.5 \mathrm{ml}$ PBS (pH 7.4 ) using groups of five mice. Deaths were recorded up to $72 \mathrm{~h}$ later. 

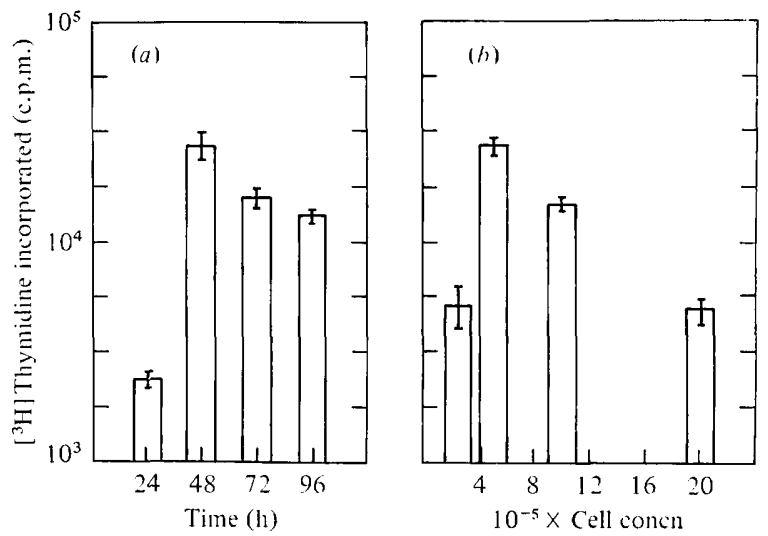

Fig. 1. (a) Stimulation of $\left[{ }^{3} \mathrm{H}\right]$ thymidine incorporation by C57BL/6 spleen cells $\left(5 \times 10^{5}\right.$ per culture) in response to $V$. cholerae LPS $(0.3 \mu \mathrm{g}$ per culture). Results are expressed as the arithmetic mean \pm S.E.M. of triplicate cultures, with the unstimulated control incorporation subtracted. The uptake of $\left[{ }^{3} \mathrm{H}\right]$ thymidine (supplied during the last $16 \mathrm{~h}$ ) in control cultures at $24,48,72$ and $96 \mathrm{~h}$ was $8331 \pm 557,5490 \pm 110,2825 \pm 72$ and $1024 \pm 28$, respectively.

(b) Proliferative response as a function of spleen cell density in culture. Different numbers of spleen cells were cultured for $48 \mathrm{~h}$ with $V$. cholerae LPS. Results are expressed as the arithmetic mean \pm S.E.M. of triplicate cultures, with the unstimulated control incorporation subtracted. The uptake of $\left[{ }^{3} \mathrm{H}\right]$ thymidine in control cultures with $2.5 \times 10^{5}, 5 \times 10^{5}, 10 \times 10^{5}$ and $20 \times 10^{5}$ cells was $2540 \pm 82,5372 \pm 125,8212 \pm 118$ and $14492 \pm 428$, respectively.

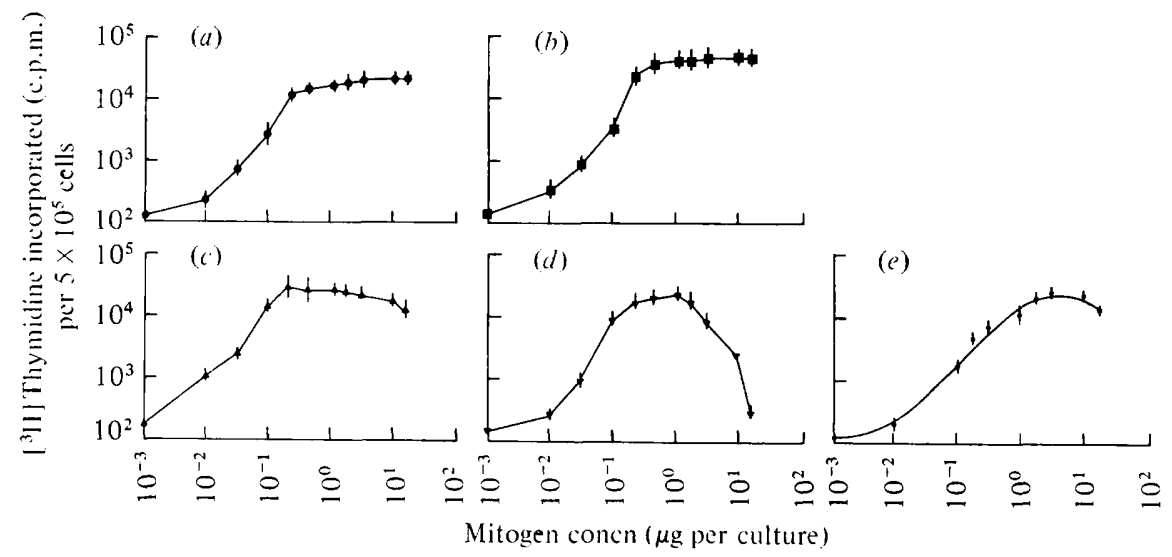

Fig. 2. Proliferative response in vitro of splenic lymphocytes from C57BL/6 mice induced by different doses of $(a)$ killed $V$. cholerae, $(b)$ spheroplasts, $(c)$ LPS, $(d)$ untreated outer membrane and (e) deoxycholate treated outer membrane. Spleen cells were cultured for $48 \mathrm{~h}$ and the results are expressed as the arithmetic mean \pm S.E.M. of triplicate cultures, with the unstimulated control incorporation subtracted.

\section{RESULTS}

Chemical composition of the cell envelope components of $V$. cholerae

The LPS preparation contained $30 \%$ carbohydrate, while the spheroplasts and the outer membrane contained 14 and $12 \%$ carbohydrate, respectively. The LPS preparation was free of any detectable contamination with protein or nucleic acids. The spheroplasts and the outer membrane contained 44 and $80 \%$ protein, respectively. The purity of the spheroplasts was checked by monitoring their formation by phase contrast microscopy. 


\title{
Table 1. Proliferation in vitro of murine $T$ and $B$ lymphocytes induced by cell envelope components of Vibrio cholerae
}

\begin{abstract}
Stimulants were added at the following doses per culture: killed $V$. cholerae, spheroplasts and outer membrane, each $1 \mu \mathrm{g}$; lipopolysaccharide, $0.3 \mu \mathrm{g}$; outer membrane proteins, $5 \mu \mathrm{g}$. Results are given as the mean \pm S.E.M. of two separate cell populations, each tested in triplicate, with the unstimulated control incorporation subtracted. Cells were cultured for $48 \mathrm{~h}$.
\end{abstract}

Maximum lymphocyte proliferative response:

$\left[{ }^{3} \mathrm{H}\right]$ thymidine incorporated (c.p.m.) per $5 \times 10^{5}$ cells

Stimulant

Killed $V$. cholerae Spheroplasts

Lipopolysaccharide

Outer membrane

Outer membrane proteins

T cells
$1518 \pm 42$
$5476 \pm 26$
$889 \pm 29$
$2725 \pm 19$
$1153 \pm 30$

The outer membrane did not contain any cytoplasmic contaminant such as NADH oxidase (Osborn et al., 1972). Also, it produced an immunoprecipitation reaction with the antiserum raised against the spheroplasts of $V$. cholerae. Thus, both the enzymic and immunochemical evidence support the authenticity of the outer membrane preparation.

\section{Mitogenic effects}

Proliferation in vitro of murine spleen lymphocytes induced by the cell envelope components of $V$. cholerae. First, the capacity of $V$. cholerae LPS to induce in vitro proliferation of murine spleen lymphocytes was tested. The maximum response was obtained when $5 \times 10^{5}$ nucleated spleen cells were cultured for $48 \mathrm{~h}$ (Fig. $1 a, b$ ). Next, the mitogenic properties of the killed whole cells, spheroplasts, outer membrane and LPS were compared. The dose-response relationships of these components are shown in Fig. 2. Each induced proliferation of murine spleen lymphocytes. The dose-response curve for whole killed cells was similar to that for spheroplasts. Increasing amounts of either component induced greater proliferation up to $5 \mu \mathrm{g}$ per culture; with higher doses the extent of incorporation of $\left[{ }^{3} \mathrm{H}\right]$ thymidine reached a plateau. LPS showed maximum stimulation at $0.3 \mu \mathrm{g}$ per culture and the outer membrane at $1.0 \mu \mathrm{g}$ per culture; with higher doses the incorporation of $\left[{ }^{3} \mathrm{H}\right]$ thymidine decreased.

Deoxycholate has been used to disaggregate non-covalently bound LPS from the outer membrane of Gram-negative bacteria (Kasper, 1976). To determine whether mitogenicity induced by the outer membrane was due to protein or carbohydrate moieties, the outer membrane of $V$. cholerae was treated with deoxycholate. By this treatment carbohydrate moieties were removed from the outer membrane. The outer membrane induced mitogenesis in murine spleen cell cultures. However, the dose-response curve for deoxycholate-treated outer membrane was shifted compared with that for the untreated outer membrane, the maximum response occurring at a higher concentration (5 to $10 \mu \mathrm{g}$ per culture).

Proliferation in vitro of murine $B$ and T lymphocytes induced by the cell envelope components of $V$. cholerae. B and $\mathrm{T}$ lymphocytes were isolated from murine spleen cells by fractionation on a nylon wool column. The proliferative responses of these fractionated lymphocytes to various cell envelope components and their derivatives are shown in Table 1. All cell envelope components including the killed whole vibrios induced proliferation, the effect being predominantly on B lymphocytes.

Stimulation in vitro of intestinal lymphocytes by LPS. Although absorption of LPS in the intestine has been reported (Nolan et al., 1977), no study involving in vitro stimulation of intestinal lymphocytes by LPS has been carried out. Therefore, we investigated the 
Table 2. Proliferation in vitro of murine lymphocytes from different organs induced by bacterial lipopolysaccharides

Stimulant LPS was added at a final concentration of $0.3 \mu \mathrm{g}$ per culture. Results are given as the mean \pm S.E.M. of two separate cell populations, each tested in triplicate. Cells were cultured for $48 \mathrm{~h}$.

Maximum lymphocyte proliferative response:

Stimulant LPS

Vibrio cholerae Ogawa 395

Salmonella typhimurium $\operatorname{Re} 595$

None $\left[{ }^{3} \mathrm{H}\right]$ thymidine incorporated (c.p.m.) per $5 \times 10^{5}$ cells

$\begin{array}{ccc}\text { Spleen } & \text { Intestine } & \text { Peyer's patches } \\ 56248 \pm 139 & 3020 \pm 139 & 6473 \pm 40 \\ 54213 \pm 138 & 2096 \pm 72 & 3967 \pm 23 \\ 6424 \pm 121 & 178 \pm 14 & 182 \pm 17\end{array}$

Table 3. Adjuvant effects of the cell envelope components of Vibrio cholerae on anti-SRBC PFC responses in murine spleens

SRBC suspension $(10 \%, \mathrm{v} / \mathrm{v} ; 0.5 \mathrm{ml})$ was injected intraperitoneally into each mouse along with LPS $(10 \mu \mathrm{g})$, spheroplasts $(100 \mu \mathrm{g})$ or outer membrane $(100 \mu \mathrm{g})$. After $5 \mathrm{~d}$, direct splenic antibody PFC were counted as described in Methods. Results are given as the mean \pm standard deviation.

$\begin{array}{lc}\quad \text { Immunizing agent } & \text { Direct (IgM) PFC per } 10^{6} \text { lymphocytes } \\ \text { SRBC } & 452 \pm 112 \\ \text { LPS +SRBC } & 1656 \pm 497 \\ \text { Spheroplasts }+ \text { SRBC } & 649 \pm 69 \\ \text { Outer membrane }+ \text { SRBC } & 653 \pm 292\end{array}$

proliferative response in vitro of murine intestinal lymphocytes to LPS preparations from $V$. cholerae and Salmonella typhimurium Re 595. In addition, we compared LPS-induced transformation of Peyer's patch cells. LPS preparations from both $V$. cholerae and $S$. typhimurium induced mitosis in intestinal lymphocytes (Table 2). The total uptake of $\left[{ }^{3} \mathrm{H}\right]$ thymidine after LPS stimulation was lower in intestinal Peyer's patch lymphocytes than in spleen cells but uptake was also lower in unstimulated enteric lymphocytes. Vibrio cholerae LPS induced similar mitogenicity in murine spleen lymphocytes to that demonstrated by $S$. typhimurium LPS.

\section{Induction of antibody plaque-forming cells}

To detect antibody formation to $V$. cholerae LPS at the cellular level, mice were immunized intraperitoneally with different doses of LPS, spheroplasts and killed bacteria. Spleens were assayed by the haemolytic plaque technique using LPS-coated SRBC as indicator cells. No anti-LPS secreting cell was observed when mice were immunized only with $V$. cholerae LPS. However, anti-LPS secreting cells were detected when a mouse received $125 \mu \mathrm{g}$ of either spheroplasts or killed whole bacteria, the number of PFC (per $10^{6}$ lymphocytes) being $150 \pm 14$ and $200 \pm 53$ (mean \pm standard deviation), respectively. To confirm that coating SRBC with LPS did not prevent anti-LPS immunoglobulins from acting on SRBC, haemolysis experiments were performed. Anti-LPS immunoglobulins lysed LPS-coated SRBC in the presence of guinea pig complement suggesting that the coating of SRBC with LPS did not prevent the action of anti-LPS on SRBC.

\section{Adjuvant action of the cell envelope components of $V$. cholerae}

To test the adjuvant properties of the cell envelope components, mice were immunized intraperitoneally with SRBC along with spheroplasts, outer membrane or LPS. Individual spleens were assayed for anti-SRBC secreting cells. A significant action (about fourfold) was observed when mice received SRBC along with LPS (Table 3). The spheroplasts and outer membrane preparations had no adjuvant effects. 


\section{Toxicity of the cell envelope components of $V$. cholerae}

Vibrio cholerae LPS, spheroplasts and outer membrane were tested for toxicity in mice. The $\mathrm{LD}_{\tilde{5} 0}$ for $V$. cholerae LPS was $500 \mu \mathrm{g}$. Neither the cell wall nor the outer membrane had detectable toxicity for mice.

\section{DISCUSSION}

We observed that both intact cells and various cell envelope components (spheroplasts, LPS and outer membrane) were mitogenic for murine spleen lymphocytes. The doseresponse curves for whole cells and spheroplasts were similar, with the proliferation of lymphocytes increasing with increasing concentration of the inducer. Presumably, this is due to the similarity between the presentation of functional surface groups for the activation of lymphocytes by the two materials. The results with intact cells agreed with recent studies with Neisseria gonorrhoeae (Brodeur et al., 1977) and with whole mycobacterial cells (Bekierkunst, 1976).

The outer membrane of Gram-negative bacteria contains a complex mixture of proteins of various molecular weights. Recently, Melchers et al. (1975) reported that lipoprotein from the outer membrane of $E$. coli having a molecular weight of 7000 is a murine B-cell mitogen. Very little is known about whether proteins other than lipoprotein are endowed with mitogenic or other biological activities. In this investigation we observed that the outer membrane preparation was mitogenic. When residual carbohydrate moieties were removed by treatment with deoxycholate, the membrane proteins induced mitosis in spleen cell cultures suggesting that the outer membrane proteins did possess mitogenic properties. Recently, Brodeur et al. (1977) have also reported that membrane proteins of $N$. gonorrhoeae are mitogenic for murine spleen lymphocytes.

We observed that all the cell envelope components of $V$. cholerae stimulated murine $\mathbf{B}$ rather than $\mathrm{T}$ lymphocytes. This observation is in agreement with the general phenomenon that most of the so-called B-cell mitogens such as LPS (Andersson et al., 1973), lipoprotein (Melchers et al., 1975) and peptidoglycans (Damais et al., 1975) have been obtained from various bacterial species.

The mechanism of action of endotoxin in vivo is not well understood. It has been reported that the mitogenic effects of LPS on lymphoid cells in vivo (Peavy et al., 1978) parallel those effects observed in vitro. Although endotoxin may be biologically active on intact bacteria (Skarnes \& Rosen, 1971), there is evidence which suggests that under certain conditions it may be released from the surface of Gram-negative bacteria (Crutchley et al., 1968; Devoe \& Gilchrist, 1973; Pike \& Chandler, 1974) and this released endotoxin might initiate biological functions. Our results support this viewpoint. LPS is known to be absorbed in the gut (Nolan et al., 1977) and we observed that $V$. cholerae LPS stimulated both the intestinal and Peyer's patch lymphocytes.

By comparing the effect of various cell envelope components of $V$. cholerae in the mouse, we found that LPS was toxic. Neither the spheroplasts nor the protein-enriched outer membrane possessed any toxic properties. In comparison with LPS of other Gram-negative bacteria such as Salmonella (Landy \& Braun, 1964), V. cholerae LPS was not among the most toxic for the mouse. Its toxicity $\left(L^{2} D_{50} 0.5 \mathrm{mg}\right.$ ) was moderate and similar to that of Salmonella enteritidis LPS (Landy \& Braun, 1964).

Among the cell envelope components tested, only LPS possessed significant adjuvant activity, the magnitude being similar to that possessed by the LPS preparation from Salmonella typhimurium LT2 (Nakano et al., 1975). The spheroplasts and the outer membrane were weak adjuvants. In this respect we find a correlation between adjuvanticity and toxicity. Our results indicate that although the cell envelope components of $V$. cholerae are predominantly murine B-cell mitogens, properties like toxicity and adjuvanticity are 
only possessed by LPS. It is believed that the lipid A moiety of LPS, which remains buried in the cell membrane (Shands, 1973; Kabir et al., 1978), mediates most of these biological properties (Lüderitz et al., 1973). Hence, in the spheroplasts the lipid moiety of LPS is not available for interaction with other cell types. Therefore, the spheroplasts or the outer membrane might not possess lipid A-mediated biological properties such as adjuvanticity or toxicity in the mouse.

We thank Dr N.F. Pierce, School of Medicine, The Johns Hopkins University, Baltimore, for his comments and criticisms during the preparation of the manuscript. This work was supported by a grant from the Rockefeller Foundation and Research Grant AI14480 from the National Institutes of Allergy and Infectious Disease, N.I.H.

\section{REFERENCES}

Andersson, J., Melchers, F., Galanos, C. \& LÜDERITZ, O. (1973). The mitogenic effect of lipopolysaccharide on bone marrow derived mouse lymphocyte. Lipid $\mathbf{A}$ as the mitogenic part of the molecule. Journal of Experimental Medicine 137, 943-953.

Axén, R., Porath, J. \& ERmback, S. (1967). Chemical coupling of peptides and proteins to polysaccharides by means of cyanogen halides. Nature, London 214, 1302-1304.

BEKIERKUNST, A. (1976). Stimulation of lymphocyte proliferation by killed mycobacteria and other bacterial species. Infection and Immunity 15, 28-32.

Brodeur, B. R., Johnson, W. M., Diena, B. B., Visentin, L. P. \& Johnson, K. G. (1977). Mitogenic activity of Neisseria gonorrhoeae surface antigens in mouse splenic lymphocyte culture. Canadian Journal of Microbiology 23, 1154-1160.

Cebra, J. J., Gearhardt, R. P. J., Robertson, S. H. \& TSENG, J. (1977). The secretory immunoglobulin A response in the gut. Biochemical Society Transactions 5, 156-169.

Crutchley, M. J., Marsh, D. G. \& Cameron, J. (1968). Biological studies on free endotoxin and a non-toxic material from culture supernatant fluids of Escherichia coli O78 K80. Journal of General Microbiology 50, 413-420.

Damais, C., Bona, C., Chedid, L., Fleck, J., Nauciel, C. \& Martin, J. P. (1975). Mitogenic effect of bacterial peptidoglycans possessing adjuvant activity. Journal of Immunology 115, 268-271.

Devoe, I. W. \& Gilchrist, J. E. (1973). Release of endotoxin in the form of cell wall blebs during in vitro growth of Neisseria meningitidis. Journal of Experimental Medicine 138, 1156-1167.

Dubois, M., Gilles, K. A., Hamilton, J. K., Rebers, P. A. \& SMith, F. (1956). Colorimetric method for determination of sugars and related substances. Analytical Chemistry 28, 350-356.

Finkelstein, R. A., Attahsampunna, P., Chulasamaya, M. \& Charunmethee, P. (1966). Pathogenesis of experimental cholera: biologic activities of purified procholeragen A. Journal of Immunology 96, 440-449.

Greaves, M. F. (1970). Biological effects of antiimmunoglobulins. Transplantation Reviews 5, 45-75.
Handwerger, B. S. \& Schwartz, R. H. (1974). Separation of murine lymphoid cells using nylon wool columns. Transplantation 18, 544-548.

Hudson, L. \& HAY, F. C. (1976). Practical Immunology, pp. 269. Oxford: Blackwell Scientific Publications.

Jerne, N. K. \& Nordin, A. A. (1963). Plaque formation in agar by single antibody producing cells. Science 140, 405.

KABIR, S. (1975). Cell surface protein of Salmonella typhimurium. Canadian Journal of Microbiology 21, 1132-1136.

Kabir, S., Rosenstreich, D. L. \& Mergenhagen, S. E. (1978). Bacterial endotoxins and cell membranes. In Bacterial Toxins and Cell Membranes, pp. 59-87. Edited by J. Jeljaszewicz \& T. Wadström. London: Academic Press.

KASPER, D. L. (1976). Chemical and biological characterisation of the lipopolysaccharide of Bacteroides fragilis subspecies fragilis. Journal of Infectious Diseases 134, 59-66.

Kass, E. H. \& WolfF, M. S. (editors) (1973). Bacterial Lipopolysaccharides. Chicago: University of Chicago Press.

Kennedy, J. R. \& RichaRdson, S. H. (1969). Fine structure of Vibrio cholerae during toxin production. Journal of Bacteriology 100, 1393-1401.

LANDY, M. \& BRAUN, W. (editors) (1964). Bacterial Endotoxins. New Jersey: Rutgers State University.

Lüderitz, O., Galanos, C., LehmanN, V., NuRMiNEN, M., RIETSCHEL, E. T., ROSENFELDER, G., Simon, M. \& Westphal, O. (1973). Lipid A: chemical structure and biological activity. Journal of Infectious Diseases 23, S17-S29.

ManN, P. (1978). The effect of various dietary restrict regimes on some immunological parameters of mice. Growth 42, 87-103.

Melchers, F., Braun, V. \& Galanos, C. (1975). The lipoprotein of the outer membrane of $E$. coli. A B-lymphocyte mitogen. Journal of Experimental Medicine 142, 473-482.

MöLLER, G. (1965). 19S antibody production against soluble lipopolysaccharide antigens by individual lymphoid cells in vitro. Nature, London 207 , 1166-1168.

Mosley, W. H., McCormack, W. M., Fahimuddin, M., Aziz, K. M. A., Rahman, A. S. M., Chowdhury, A. K. M. A., Martin, A. R., Feeley, J. C. \& Philips, R. A. (1969). Report of the 1966-67 cholera vaccine field trial in rural 
East Pakistan. 1. Study design and results of the first year of observation. Bulletin of the World Health Organization 40, 177-185.

Nakano, M., Uchryama, T., Tanabe, M. J. \& SaIto, K. (1975). Non-specific elicitation of antibody forming cells in mouse spleen by bacterial lipopolysaccharide. Japanese Journal of Microbiology 19, 141-148.

Nolan, J. P., Have, D. K., McDevitT, J. J. \& ALI, M. V. (1977). In vitro studies of intestinal endotoxin absorption. 1. Kinetics of absorption in the isolated everted gut sac. Gastroenterology 72, 434-439.

Osborn, M. J., Gander, J. E., Parisi, E. \& Carson, J. (1972). Mechanism of assembly of the outer membrane of Salmonella typhimurium. Journal of Biological Chemistry 247, 3962-3972.

Osborn, M. J. \& Munson, R. (1975). Separation of the inner (cytoplasmic) and outer membranes of gram-negative bacteria. Methods in Enzymology 67, 642-653.

Peavy, D. L., Baughn, R. E. \& Musher, D. M. (1978). Mitogenic activity of bacterial lipopolysaccharides in vivo: morphological and functional characterization of responding cells. Infection and Immunity 19, 71-78.

Pike, R. M. \& Chandler, C. H. (1974). The spontaneous release of somatic antigen from
Vibrio cholerae. Journal of General Microbiology 81, 59-67.

Rittenhouse, H. G., McFadden, B. A., Shumway, K. L. \& Heptinstall, J. (1973). Cell surface protein of Pseudomonas (Hydrogenomonas) facilis. Journal of Bacteriology 115, 330-340.

Schnartman, C. A. (1971). Solubilization of the cytoplasmic membrane of Escherichia coli by Triton X-100. Journal of Bacteriology 108, $545-552$.

SHANDS, J. W. (1966). Localization of somatic antigen on gram-negative bacteria using ferritin antibody conjugates. Annals of the New York Academy of Sciences 133, 292-298.

SHANDS, J. W., JR (1973). Affinity of endotoxin for membranes. Journal of Infectious Diseases 23, S197-S201.

Skarnes, R. C. \& Rosen, F. S. (1971). Host dependent detoxification of bacterial endotoxin. In Microbial Toxins, vol. 5, pp. 151-164. Edited by S. Kadis, G. Weinbaum \& S. J. Ajl. New York: Academic Press.

WESTPHAL, O. \& JANN, K. (1965). Bacterial lipopolysaccharides. Methods in Carbohydrate Chemistry 5, 83-96.

Westphal, O., Lüderitz, O. \& Bister, F. (1952). Úber die Extraktion von Bakterien mit Phenolwasser. Zeitschrift für Naturforschung B7, 148-155. 